\title{
PENGARUH JARAK TANAM DAN MULSA TERHADAP PERTUMBUHAN DAN HASIL TANAMAN TOMAT (Lycopersicon esculentum Mill) PADA MUSIM PENGHUJAN
}

\author{
Amelia Nur Suprianto ${ }^{1)}$ dan Tri Kurniastuti ${ }^{1)}$
}

1) Mahasiswa Prodi Agroteknologi, Fakultas Pertanian, Universitas Islam Balitar 2) Dosen Prodi Agroteknologi, Fakultas Pertanian, Universitas Islam Balitar

\begin{abstract}
This research aims 1) To determine the effect of interaction of different plant spacing and the provision of mulch to growth and yield of tomato plants. 2) To know the different spacing affect the growth and yield of tomato plants. 3) To know the use of mulch type effect on growth and yield of tomato plants. This research was conducted by using Randomized Block Design in Factorial (RAK) with 2 factors, first factor is plant spacing (J) consisting of 3 levels ie $40 \times 30 \mathrm{~cm}(J 1), 40 \times 50 \mathrm{~cm}(J 2), 40 \times 70 \mathrm{~cm}(J 3)$. The second factor is mulch (M) consisting of 3 levels ie: without mulch (MO / control), straw mulch (M1), plastic mulch (M2). The variables observed were plant height, number of branches, number of bunches, number of fruit, and fruit weight. Data were analyzed by using variance analysis (Anova), $5 \%$ level. The results showed that: There was no interaction between plant spacing and mulch on growth and yield of tomato plants. Treatment spacing $40 x 50$ (J2) effect on the number of bunches of $35 \mathrm{HST}$, the weight of the first harvest fruit and total fruit weight. The use of straw mulch type (M1) has an effect on plant height, number of branches, number of 35 HST bunches, and total fruit weight.
\end{abstract}

Keywords: Planting Distance, Mulch, Growth and Tomato Results.

\section{PENDAHULUAN}

Tomat (Lycopersicon esculentum Mill) termasuk dalam jenis sayuran yang sangat popular dikalangan masyarakat. Ciri khas tomat yaitu mempunyai rasa buah yang asam manis, berbeda dengan buah lainnya serta dapat menambah kesegaran tubuh. Tomat bermanfaat bagi tubuh karena mengandung zat-zat yang diperlukan untuk kesehatan tubuh. Buah tomat mengandung protein, karbohidrat, lemak, kalsium, fosfor, zat besi dan juga mengandung vitamin $\mathrm{A}$, vitamin $\mathrm{B}$, vitamin $\mathrm{C}$, yang cukup tinggi. bagian yang dapat dimakan 95\% (Wiryanta, 2002).

Berdasarkan Statistik Produksi Hortikultura (2014) tomat dengan kontribusi produksi sebesar 915.987 ton atau sekitar 7,69 persen terhadap produksi sayuran nasional berada pada urutan kelima. Sentra produksi tomat di Indonesia adalah Pulau Jawa dengan total produksi sebesar 434.202 ton atau sekitar 47,40 persen dari total produksi tomat nasional. Adapun provinsi penghasil tomat terbesar adalah Jawa Barat dengan produksi sebesar 304.687 ton 33,26 persen dari total produksi tomat nasional, diikuti Jawa Timur dan Jawa Tengah. Sedangkan provinsi penghasil tomat terbesar di luar Jawa adalah Sumatera Utara, dengan produksi sebesar 84.339 ton atau sekitar 9,21 persen dari total produksi tomat nasional, diikuti oleh Sumatera Barat. 
Produksi tanaman yang maksimum dapat diperoleh dengan penerapan beberapa teknik budidaya yang tepat diantaranya adalah penggunaan jarak tanam tepat dan penggunaan mulsa. Salah satu teknik budidaya yang mengatur tata letak dan populasi tanaman dengan jarak tanam yang pasti menurut dua arah tertentu dalam satu area. Melalui pemilihan jarak

tanam yang tepat tingkat persaingan antar maupun intern tanaman dapat ditekan serendah mungkin. Selain itu pemilihan jarak tanam juga dapat mengoptimumkan kemampuan tanaman dalam memanfaatkan unsur-unsur yang dibutuhkan dalam proses fotosintesis seperti cahaya matahari, air dan hara. Pengaturan jarak tanam sangat berkaitan erat dengan kerapatan tanaman.

Menurut Yani dan Trisnawati (2007) jarak tanam yang yang baik untuk tanaman tomat adalah sekitar $80 \times 40 \mathrm{~cm}$ atau $60 \times 40 \mathrm{~cm}$. Penentuan jarak tanam tergantung pada daya tumbuh benih, kesuburan tanah, musim, serta varietas yang ditanam. Benih yang daya tumbuhnya rendah perlu ditanam dengan jarak tanam yang lebih rapat. Penanaman pada musim kemarau, diperkirakan akan kekurangan air, sehingga perlu ditanam dengan jarak yang lebih rapat.

Secara umum penggunaan mulsa merupakan bagian dari teknik budidaya tanaman yang perlu mendapat perhatian. Mulsa berfungsi untuk menghindari kehilangan air melalui penguapan dan menekan pertumbuhan gulma. Pemberian mulsa berpengaruh terhadap kondisi tanah dan iklim mikro. Mulsa dapat menekan pertumbuhan gulma serta memberikan efek positif bagi tanaman. Menurut Sumarna dan Suwandi (1990) dalam Amisnaipa (2005) menyatakan bahwa di lahan kering atau pada musim kemarau perlakuan pemulsaan berpengaruh terhadap pertumbuhan tanaman tomat dan dapat menghasilkan buah total sebesar 21,4 ton per hektar dibandingkan dengan perlakuan tanpa mulsa yang menghasilkan buah total 13,8 ton per hektar. Menurut Rohman Wakhid dkk (2012) bahwa pada musim penghujan penggunaan mulsa plastik berpengaruh terhadap produksi terutama pada bobot serta jumlah umbi pada bawang merah. Dalam hal ini, pengaruh mulsa dapat memperbaiki kondisi ekologi tanah, diantaranya fluktuasi kelembaban dan suhu tanah yang berpengaruh terhadap pertumbuhan vegetatif tanaman yang peka terhadap perubahan suhu.

Tujuan penelitian ini : 1) Untuk mengetahui pengaruh interaksi jarak tanam dan penggunaa jenis mulsa terhadap pertumbuhan dan hasil tanaman tomat. 2) Untuk mengetahui jarak tanam yang berbeda berpengaruh terhadap pertumbuhan dan hasil tanaman tomat. 3) Untuk mengetahui penggunaan jenis mulsa berpengaruh terhadap pertumbuhan dan hasil tanaman tomat.

\section{Tempat dan Waktu}

\section{METODOLOGI}

Penelitian ini dilakukan di Desa darungan, Kecamatan Kademangan,

Kabupaten Blitar. Pelaksanaan ini dimulai dari bulan Februari sampai dengan bulan April 2017 yang telah memasuki musim Penghujan.

\section{Alat dan Bahan}

Alat yang digunakan dalam penilitian ini terdiri dari cangkul, sabit, meteran, talirafia, ajir, sprayer, timbangan, alat tulis, penggaris, dan papan nama.

Adapun bahan yang digunakan dalam penelitian yaitu benih tomat, mulsa organic dari jerami, mulsa plastic hitam perak. 


\section{Rancangan Percobaan}

Metode yang dipakai dalam penelitian ini adalah Rancangan Acak kelompok yang disusun secara Faktorial dengan 2 (dua) factor yang diulang 3 (tiga) kali. Factor pertama adalah jarak tanam (J) yang terdiri dari 3 taraf yaitu :

$\mathrm{J} 1=$ jarak tanam $40 \times 30$

$\mathrm{J} 2=$ jarak tanam $40 \times 50$

$\mathrm{J} 3=$ jarak tanam $40 \times 70$

Sedangkan factor kedua yaitu mulsa (M) yang terdiri dari 3 taraf yaitu :

M0 = Tanpa mulsa

M1 = Mulsa jerami ketebalan $9 \mathrm{~cm}$

M2 = Mulsa plastic hitam perak

Dengan demikian diperoleh Sembilan kombinasi perlakuan dan masing masing perlakuan diulang tiga kali ulangan.

\section{Analisis Data}

Analisis data menggunakan sidik ragam (analysis of variance) pada taraf 5\%, bila terdapat perbedaan pengaruh di antara perlakuan, maka untuk membandingkan antara dua rata - rata perlakuan dilanjutkan dengan uji BNJ.

\section{Variabel Pengamatan}

Dalam penelitian ini hal yang perlu diamati yaitu : tinggi tanaman, jumlah cabang, jumlah tandan, jumlah buah per tanaman, bobot buah per tanaman.

\section{HASIL PENELITIAN}

\section{Tinggi Tanaman}

Berdasarkan hasil analisis sidik ragam (ANOVA) pada taraf 5\% menunjukkan bahwa tidak terdapat interaksi antara perlakuan jarak tanam dan mulsa terhadap tinggi tanaman tomat pada semua umur pengamatan.

Tabel 1. Pengaruh Jarak Tanam (J) dan Mulsa (M) Terhadap Tinggi Tanaman Tomat Pada Berbagai Umur Pengamatan.

\begin{tabular}{lcccc}
\hline \multirow{2}{*}{ Perlakuan } & \multicolumn{4}{c}{ Tinggi Tanaman (cm) } \\
& 14 HST & 21 HST & 28 HST & 35 HST \\
\hline Jarak Tanam & & & \\
J1 (40x30) & $29.62 \mathrm{a}$ & $47.51 \mathrm{a}$ & $58.47 \mathrm{a}$ & $71.90 \mathrm{a}$ \\
J2 (40x50) & $29.67 \mathrm{a}$ & $45.77 \mathrm{a}$ & $59.10 \mathrm{a}$ & $73.77 \mathrm{a}$ \\
J3 (40x70) & $29.82 \mathrm{a}$ & $44.55 \mathrm{a}$ & $57.31 \mathrm{a}$ & $71.35 \mathrm{a}$ \\
Jenis Mulsa & & & & \\
M2 (Mulsa Plastik) & $28.88 \mathrm{a}$ & $42.37 \mathrm{a}$ & $54.67 \mathrm{a}$ & $68.81 \mathrm{a}$ \\
M0 (Tanpa Mulsa) & $29.74 \mathrm{ab}$ & $46.44 \mathrm{ab}$ & $59.52 \mathrm{ab}$ & $71.80 \mathrm{ab}$ \\
M1 (Mulsa jerami) & $30.48 \mathrm{~b}$ & $48.95 \mathrm{~b}$ & $60.69 \mathrm{~b}$ & $76.41 \mathrm{~b}$ \\
\hline
\end{tabular}

Keterangan : Angka-angka yang diikuti dengan huruf yang sama pada baris dan kolom yang sama tidak berbeda nyata pada uji Duncan $(\alpha=0,05)$. 
Perlakuan jarak tanam $(\mathrm{J})$ tidak memberikan pengaruh nyata terhadap tinggi tanaman tomat pada semua umur pengamatan. Namun pada perlakuan jenis Mulsa (M) memberikan pengaruh nyata terhadap tinggi tanaman tomat pada umur pengamatan 14 , 21, 28, 35 HST (Tabel 1). Dari tabel 1 diatas bahwa pada perlakuan jenis mulsa (M) berpengaruh terhadap tinggi tanaman. perlakuan terbaik yaitu pada mulsa jerami (M1. hal ini diduga bahwa penggunaan mulsa jerami mempengaruhi tinggi tanaman tomat karena pada area sekitar tanaman yang diberi mulsa jerami tidak terdapat gulma sehingga tidak ada kompetisi dalam memperebutkan unsur hara. Selain itu, tanaman yang diberi mulsa jerami kelembabannya dapat terjaga serta mulsa jerami juga dapat menambah bahan organic tanah sehingga dapat memicu tinggi tanaman tomat pada fase vegetatif. Hal ini sesuai dengan pernyataan Sutejo (2002) bahwa penggunaan mulsa jerami dapat mengurangi pertumbuhan gulma serta menjaga kelembaban tanah tetap stabil agar mikroorganisme dalam tanah tetap melakukan aktifitasnya dalam mendekomposisi bahan organic untuk mensuplai unsur hara yang di butuhkan oleh tanaman pada pertumbuhan vegetatifnya.

\section{Jumlah Cabang}

Berdasarkan hasil analisis sidik ragam (ANOVA) pada taraf 5\% menunjukkan bahwa interaksi antara perlakuan jarak tanam dan mulsa tidak ada perbedaan yang nyata terhadap jumlah cabang tanaman tomat pada semua umur pengamatan. Perlakuan jarak tanam (J) tidak berpengaruh nyata terhadap jumlah cabang tanaman tomat pada semua umur pengamatan. Namun pada perlakuan jenis mulsa (M) memberikan pengaruh nyata terhadap jumlah cabang tanaman tomat pada umur 21 HST, 28 HST dan 35 HST pada tanaman tomat. Seperti pada tabel 2 di bawah ini :

Tabel 2. Pengaruh Jarak Tanam (J) dan Mulsa (M) Terhadap Jumlah Cabang Tanaman Tomat.

\begin{tabular}{llll}
\hline \multirow{2}{*}{ Perlakuan } & \multicolumn{3}{c}{ Jumlah Cabang } \\
& 21 HST & 28 HST & 35 HST \\
\hline Jarak Tanam & & & \\
J1 (40x30) & $0.85 \mathrm{a}$ & $1.79 \mathrm{a}$ & $2.89 \mathrm{a}$ \\
J2 (40x50) & $0.96 \mathrm{a}$ & $1.89 \mathrm{a}$ & $3.07 \mathrm{a}$ \\
J3 (40x70) & $0.81 \mathrm{a}$ & $1.81 \mathrm{a}$ & $3.07 \mathrm{a}$ \\
Jenis Mulsa & & & \\
M2 (Mulsa Plastik) & $0.85 \mathrm{a}$ & $1.67 \mathrm{a}$ & $2.74 \mathrm{a}$ \\
M0 (Tanpa Mulsa) & $0.74 \mathrm{a}$ & $1.78 \mathrm{a}$ & $3.04 \mathrm{ab}$ \\
M1 (Mulsa jerami) & $1.04 \mathrm{~b}$ & $2.04 \mathrm{~b}$ & $3.26 \mathrm{~b}$ \\
\hline
\end{tabular}

Keterangan : Angka-angka yang diikuti dengan huruf yang sama pada baris dan kolom yang sama tidak berbeda nyata pada uji Duncan $(\alpha=0,05)$.

Pada tabel 2 di atas bahwa pada perlakuan jenis mulsa berpengaruh terhadap jumlah cabang. Perlakuan terbaik yaitu pada perlakuan mulsa jerami (M1). hal ini diduga bahwa penggunaan mulsa jerami dapat mempengaruhi jumlah cabang tanaman tomat 
yang tumbuh di karenakan mulsa jerami mampu menjaga kelembaban sekitar area tanaman dan mulsa jerami juga dapat menyumbang bahan organik yang bisa dimanfaatkan oleh tanaman sehingga dapat berpengaruh terhadap jumlah cabang. Fauzan (2002) menyatakan bahwa penutupan tanah dengan bahan organic mampu meningkatkan penyerapan air serta mengurangi penguapan air pada permukaan tanah. Selain itu mulsa jerami padi dapat memperbaiki kesuburan, struktur dan secara tidak langsung akan mempertahankan agregasi dan porositas tanah sehingga dapat mempertahankan kapasitas tanah menahan air, setelah terjadinya dekomposisi bahan organik.

\section{Jumlah Tandan}

Berdasarkan analisis sidik ragam (ANOVA) pada taraf 5\% bahwa interaksi dari perlakuan jarak tanam $(\mathrm{J})$ dan mulsa $(\mathrm{M})$ tidak berpengaruh nyata terhadap jumlah tandan tanaman tomat pada semua umur pengamatan. Pada perlakuan jarak tanam (J) tidak terjadi perbedaan yang nyata terhadap jumlah tandan tanaman tomat pada umur pengamatan yaitu 21 HST, sedangkan pada umur 28 HST dan 35 HST terjadi perbedaan yang nyata. Namun pada perlakuan jenis mulsa (M) juga tidak terdapat perbedaan yang nyata pada umur pengamatan 21 HST, dan 28 HST tetapi berpengaruh nyata pada umur 35 HST terhadap jumlah tandan tanaman tomat. seperti pada tabel 3 di bawah ini :

Tabel 3. Pengaruh Jarak Tanam (J) dan Mulsa (M) Terhadap Jumlah Tandan Tanaman Tomat.

\begin{tabular}{lccc}
\hline \multirow{2}{*}{ Perlakuan } & \multicolumn{3}{c}{ Jumlah Tandan } \\
& 21 HST & $28 \mathrm{HST}$ & $35 \mathrm{HST}$ \\
\hline Jarak Tanam & $1.85 \mathrm{a}$ & $4.66 \mathrm{a}$ & $7.07 \mathrm{a}$ \\
J3 (40x70) & $1.92 \mathrm{a}$ & $4.74 \mathrm{ab}$ & $7.25 \mathrm{a}$ \\
J1 (40x30) & $2.00 \mathrm{a}$ & $5.00 \mathrm{~b}$ & $7.77 \mathrm{~b}$ \\
J2 (40x50) & & & \\
Jenis Mulsa & $1.96 \mathrm{a}$ & $4.70 \mathrm{a}$ & $7.22 \mathrm{a}$ \\
M0 (Tanpa Mulsa) & $1.85 \mathrm{a}$ & $4.77 \mathrm{a}$ & $7.18 \mathrm{a}$ \\
M2 (Mulsa Plastik) & $1.96 \mathrm{a}$ & $4.92 \mathrm{a}$ & $7.70 \mathrm{~b}$ \\
M1 (Mulsa jerami) & & & \\
\hline
\end{tabular}

Keterangan : Angka-angka yang diikuti dengan huruf yang sama pada baris dan kolom yang sama tidak berbeda nyata pada uji Duncan $(\alpha=0,05)$.

Pada tabel 3 di atas bahwa perlakuan jarak tanam berpengaruh terhadap jumlah tandan pada umur 28 HST dan 35 HST, dengan perlakuan terbaik yaitu pada perlakuan jarak tanam 40x50 (J2). Hal ini diduga bahwa pada perlakuaan jarak tanam 40x50 cm tidak terjadi tumpang tindih antara tanaman satu dengan tanaman lainnya sehingga kompetisi dalam penyerapan sinar matahari, air dan unsur hara tidak terlalu tinggi dapat memenuhi kebutuhan tanaman untuk pertumbuhan pada fase generatif. Menurut Pima (2009) bahwa Perakaran, tajuk tanaman dan kondisi tanah menentukan jarak tanam antar tanaman. karena berkaitan dengan penyerapan sinar matahari dan unsur hara oleh tanaman, sehingga akan mempengaruhi pertumbuhan dan produksi tanaman. Tanaman 
yang memiliki jarak tanam yang lebih luas mendapatkan sinar matahari dan unsur hara yang cukup sehingga memperkecil persaingan antar tanaman.

Pada perlakuan mulsa (M) berpengaruh nyata pada umur 35 HST terhadap jumlah tandan dengan perlakuan terbaik yaitu pada mulsa jerami (M1). Hal ini di duga bahwa perlakuan pemberian mulsa jerami mampu menjaga kelembaban tanah, mengurangi fluktuasi suhu tanah selain itu mulsa organic juga mensuplai kebutuhan $\mathrm{P}$ untuk tanaman dan dapat mensuplai unsur hara lainnya. Menurut Raihan et al., (1999) dalam Dewi Ratih. R. D dkk (2013) menyatakan bahwa penggunaan mulsa organic dapat mempertahankan kelembaban tanah sehingga kebutuhan air dapat tersedia bagi tanaman dibanding tanpa mulsa. Selain itu, penggunaan mulsa organic juga memberikan hasil yang baik karena mensuplai kebutuhan $\mathrm{P}$ bagi tanaman serta dapat mensuplai unsur hara lainnya.

\section{Jumlah buah}

Berdasarkan hasil analisis sidik ragam (ANOVA) pada taraf 5\% menunjukkan bahwa tidak terdapat interaksi antara perlakuan jarak tanam dan mulsa terhadap jumlah buah per tanaman dan jumlah buah total. Perlakuan jarak tanam (J) tidak berpengaruh nyata terhadap jumlah buah per tanaman dan jumlah buah total tanaman tomat pada semua panenan. Pada perlakuan jenis mulsa (M) tidak memberikan pengaruh nyata terhadap jumlah buah pertanaman dan jumlah buah total tanaman tomat pada semua panenan. Seperti pada tabel 4 di bawah ini :

Tabel 4. Pengaruh Jarak Tanam (J) dan Mulsa (M) Terhadap Jumlah Buah Tanaman Tomat.

\begin{tabular}{lcccc}
\hline \multirow{2}{*}{ Perlakuan } & \multicolumn{4}{c}{ Jumlah Buah } \\
& Panen 1 & Panen 2 & Panen 3 & Total \\
\hline Jarak Tanam & & & & \\
J1 (40x30) & $2.04 \mathrm{a}$ & $4.63 \mathrm{a}$ & $6.96 \mathrm{a}$ & $13.63 \mathrm{a}$ \\
J2 (40x50) & $2.30 \mathrm{a}$ & $4.67 \mathrm{a}$ & $7.04 \mathrm{a}$ & $14.00 \mathrm{a}$ \\
J3 (40x70) & $2.11 \mathrm{a}$ & $4.56 \mathrm{a}$ & $6.89 \mathrm{a}$ & $13.56 \mathrm{a}$ \\
Jenis Mulsa & & & & \\
M0 (Tanpa Mulsa) & $2.07 \mathrm{a}$ & $4.52 \mathrm{a}$ & $6.89 \mathrm{a}$ & $13.48 \mathrm{a}$ \\
M1 (Mulsa jerami) & $2.19 \mathrm{a}$ & $4.74 \mathrm{a}$ & $7.07 \mathrm{a}$ & $14.00 \mathrm{a}$ \\
M2 (Mulsa Plastik) & $2.19 \mathrm{a}$ & $4.59 \mathrm{a}$ & $6.93 \mathrm{a}$ & $13.70 \mathrm{a}$ \\
\hline
\end{tabular}

Keterangan : Angka-angka yang diikuti dengan huruf yang sama pada baris dan kolom yang sama tidak berbeda nyata pada uji Duncan $(\alpha=0,05)$.

Pada tabel 4 di atas Pada perlakuan jarak tanam (J) dan jenis mulsa (M) tidak memberikan pengaruh nyata terhadap jumlah buah dan jumlah buah total tanaman tomat tetapi pada perlakuan jarak tanam 40x50 (J2) dan mulsa jerami (M1) memberikan sedikit hasil tertingginya dari perlakuan lainnya. Hal ini diduga kebutuhan intensitas cahaya yang diperoleh tanaman sangat terbatas, sehingga kesempatan daun untuk melakukan fotosintesis menjadi sedikit. Selain itu, pada saat melakukan penelitian factor iklim (curah hujan) juga menjadi kendala sehingga berpengaruh terhadap munculnya bunga yang juga mempengaruhi jumlah buah yang dihasilkan. Menurut Widyasari, (2011) dalam Hendra 
T. M dkk (2013) yang menyatakan bahwa, ketersediaan cadangan makanan dalam tubuh tanaman dipengaruhi oleh proses metabolisme yang dilakukan daun, daun berfungsi sebagai tempat penghasil makanan bagi tanaman yang digunakan sebagai sumber energi aktifitas pertumbuhan termasuk pembentukan bunga pada fase generatif. Sehingga jumlah bunga akan mempengaruhi jumlah buah yang dihasilkan oleh tanaman tersebut.

\section{Bobot Buah}

Berdasarkan hasil analisis sidik ragam (ANOVA) pada taraf 5\% menunjukkan bahwa tidak terdapat interaksi antara perlakuan jarak tanam dan mulsa terhadap bobot buah per tanaman dan bobot buah total pada tanaman tomat. Perlakuan jarak tanam (J) berpengaruh nyata terhadap bobot buah per tanaman tomat pada panen ke 1 dan berpengaruh nyata pada bobot buah total, sedangkan pada panen ke 2 dan panen ke 3 tidak terdapat pengaruh nyata terhadap bobot buah tanaman tomat. Pada perlakuan jenis mulsa (M) tidak memberikan pengaruh nyata terhadap bobot buah buah per tanaman tomat pada waktu panen pertama dan panen kedua, namun berbeda nyata terhadap bobot buah pada waktu panen ketiga dan bobot buah total. Seperti pada tabel 5 di bawah ini :

Tabel 5. Pengaruh Jarak Tanam (J) dan Mulsa (M) Terhadap Bobot Buah Tanaman Tomat.

\begin{tabular}{lcccc}
\hline \multirow{2}{*}{ Perlakuan } & \multicolumn{4}{c}{ Bobot Buah (g) } \\
& Panen 1 & Panen 2 & Panen 3 & Total \\
\hline Jarak Tanam & & & \\
J1 (40x30) & $130 \mathrm{a}$ & $260 \mathrm{a}$ & $400 \mathrm{a}$ & $790 \mathrm{a}$ \\
J3 (40x70) & $130 \mathrm{a}$ & $250 \mathrm{a}$ & $400 \mathrm{a}$ & $780 \mathrm{a}$ \\
J2 (40x50) & $150 \mathrm{~b}$ & $270 \mathrm{a}$ & $410 \mathrm{a}$ & $830 \mathrm{~b}$ \\
Jenis Mulsa & & & & \\
M0 (Tanpa Mulsa) & $130 \mathrm{a}$ & $250 \mathrm{a}$ & $390 \mathrm{a}$ & $780 \mathrm{a}$ \\
M2 (Mulsa Plastik) & $130 \mathrm{a}$ & $260 \mathrm{a}$ & $400 \mathrm{ab}$ & $790 \mathrm{a}$ \\
M1 (Mulsa jerami) & $140 \mathrm{a}$ & $270 \mathrm{a}$ & $420 \mathrm{~b}$ & $820 \mathrm{~b}$ \\
\hline
\end{tabular}

Keterangan : Angka-angka yang diikuti dengan huruf yang sama pada baris dan kolom yang sama tidak berbeda nyata pada uji Duncan $(\alpha=0,05)$.

Pada tabel 5 di atas menunjukkan bahwa perlakuan jarak tanam dan mulsa tidak terdapat interaksi yang nyata pada variabel bobot buah total. Pada perlakuan jarak tanam (J) berpengaruh nyata terhadap bobot buah total. Pada perlakuan jarak tanam yang memberikan hasil terbaik yaitu pada perlakuan J2 (40x50). Hal ini diduga bahwa jarak tanam yang tepat dapat mengoptimumkan kemampuan tanaman dalam memanfaatkan unsur-unsur yang dibutuhkan dalam proses fotosintesis seperti cahaya matahari, air dan hara sehingga dapat berpengaruh terhadap bobot buah total. Sulisbury dan Ros (1992) dalam Rusworo dkk (2012) menyatakan bahwa pengaturan jarak tanam yang tepat pada tanaman akan mendapatkan cahaya matahari secara optimum apabila di manfaatkan semaksimal mungkin maka akan diperoleh hasil fotosintat yang lebih besar. 
Selain itu perlakuan mulsa (M) berpengaruh terhadap bobot buah total dengan perlakuan mulsa (M) yang memberikan hasil terbaik yaitu perlakuan M1 (mulsa jerami). Hal ini diduga bahwa penggunaan mulsa jerami dapat memeberikan dampak positif terhadap tanaman tomat karena mampu memperbaiki sifat fisik, kimia dan bologi tanah, selain menjaga kelembaban tanah, mulsa jerami dapat menambah bahan organik tanah dalam rentan waktu tertentu. Karena terjadi perombakan bahan organic pada mulsa jerami, dapat meningkatkan unsur hara yang dapat memperbaiki sifat fisik, kimia, dan biologi tanah. Hal ini sesuai dengan pernyataan Mayun, (2007) yang menyatakan bahwa mulsa jerami memiliki efek menurunkan suhu tanah dan meminimalisir evaporasi sehingga bisa menjaga keberadaan air tanah dan mampu meningkatkan produksi tanaman tomat. Selain itu pemberian mulsa jerami juga memberikan manfaat pada tanaman tomat itu sendiri serta sangat menguntungkan baik secara biologi, kimia, dan fisik tanah.

\section{KESIMPULAN}

Tidak terdapat pengaruh interaksi jarak tanam dan penggunaan jenis mulsa terhadap pertumbuhan dan hasil tanaman tomat di semua umur pengamatan.

Jarak tanam yang berbeda berpengaruh nyata pada jumlah tandan dan variabel bobot buah pada pada waktu panen pertama. Serta pada variabel bobot buah total memberikan pengaruh yang nyata. Perlakuan jarak tanam terbaik yaitu pada perlakuan jarak tanam 40x50 cm (J2).

Penggunaan jenis mulsa berpengaruh nyata pada variabel tinggi tanaman, jumlah cabang pada semua umur pengamatan dan jumlah tandan pada umur 35 HST. Pada variabel bobot buah memberikan pengaruh nyata pada waktu panen ketiga. serta pada variabel bobot buah total memberikan pengaruh yang nyata. Perlakuan terbaik pada penggunaan jenis mulsa yaitu pada mulsa jerami.

\section{DAFTAR PUSTAKA}

Agromedia, Redaksi.2007. Panduan Lengkap Budidaya Tomat. Agromedia, Jakarta.

Damaiyanti, Dewi.R.R. dkk. 2013. Kajian Penggunaan Macam Mulsa Organic Pada Pertumbuhan dan Hasil Tanaman Cabai Besar (Capsicum Annum L.) Jurnal Produksi Tanaman. Jurusan Budidaya Pertanian Fakulatas Pertanian Universitas Brawijaya Malang. Vol. 1 No. 2

Darmawan, I.G.P, dkk. 2014. Pengaruh Penggunaan Mulsa Plastic Terhadap Hasil Tanaman Cabai Rawit (Capsicum frutescens L.) di Luar Musim di Desa Kerta. eJurnal Agroekoteknologi Tropika. Vol. 3, No. 3, Juli 2014

Direktorat Jenderal Hortikultura, Kementerian Pertanian, Statistik Produksi Hortikuluta Tahun 2014

Fauzan, A. 2002. Pemanfaatan Mulsa Dalam Pertanian Berkelanjutan. Pertanian Organik. Malang. H. 182-187.

Kadarso. 2008. Kajian Penggunaan Jenis Mulsa Terhadap Hasil Tanaman Cabai Merah Varietas Red Charm. Agros. 10(2) :134-139 
Kumalasari, N. R. dkk. 2005. Pengaruh Pemberian Mulsa Chromolaena (L.) Kings and Robbins pada Kandungan Mineral P dan N Tanah Latosol dan Produktivitas Hijauan Jagung (Zea mays L.). 23:29-36

Kusuma, Agus.H. dkk. 2014. Pengaruh Varietas dan Ketebalan Mulsa Jerami Padi pada Pertumbuhan dan Hasil Tanaman Tomat (Lycopersicum Esculentum Mill.). Fakultas Pertanian Universitas Panca Marga.

Mato, Hendra T dkk. 2013. Pengaruh Pemberian Mulsa Organik dan Jarak Tanam yang Berbeda Terhadap pertumbuhan dan Produksi Tanaman Tomat. Jurnal

Mayun, I.D., 2007. Efek Mulsa Jerami Padi dan Pupuk Kandang Terhadap Pertumbuhan dan Hasil Bawang Merah di Daerah Pesisir. Agritop.

Mulyatri, 2003. Kajian Pemberian Air dan Mulsa Terhadap Iklim Mikro Pada Tanaman Cabai di Tanah Entisol. J. Ilmu Tanah dan Lingkungan. 4 (1) : 41-49.

Noorhadi dan Sudadi, 2003. Kajian Pemberian Air dan Mulsa terhadap Iklim Mikro pada Tanaman Cabai di Tanah Entisol. Fakultas Pertanian UNS Surakarta. Jurnal Ilmu Tanah dan Lingkungan, 4(1): 41-49.

Paudi, Rois. dkk. 2013. Pertumbuhan dan produksi Tanaman Tomat (Solanum lycopersicum L) Varietas Pertama F1 Berdasarkan Pengolahan Tanah dan Jarak Tanam yang Berbeda. Program Studi Agroteknologi Fakultas Pertanian Universitas Negeri Gorontalo.

Pitojo, Setijo. 2005. Bertanam Tomat. Kanisius. Yogyakarta.

Purba, M. Afaddli. dkk. 2015. Pengaruh Pemberian Fosfat Alam dan Bahan Organic pada Tanah Sulfat Masam Potensial Terhadap P Tersedia Tanah dan Produksi Padi (Oryza Sativa L) Program Studi Agroekoteknologi Fakultas Pertanian USU Medan. Jurnal Online Agroekoteknologi. Vol. 3 No. 3 : 938-934

Rismunandar, 2001. Tanaman Tomat. Sinar Baru Algensindo, Bandung.

Rusworo, dkk. 2011. Produksi Cabai Merah Besar (Capsicum Annum L.) pada Bebagai Jarak Tanam dan Takaran Mulsa. Jurnal Penelitian Agronomi. Program Studi Agronomi Program Pasca Sarjana UNHALU. Vol. 1 No. 2 Hal. 115-120

Sucianti. 2015. Interaksi Iklim (Curah Hujan) Terhadap Pertumbuhan dan Hasil Tanaman pangan di Kabupaten Pacitan. Balai penelitian Agroklimat dan Hidrologi Balitbang Kementan. Jawa Barat. Indonesia. Jurnal PROS SEM HAS NAS MASY BIODIV INDO. Vol. 1 No. 2. Hal. 358-365 